\title{
Pre-Extension Demonstration of Improved Maize Technology at Midland Districts of Guji Zone, Southern Oromia, Ethiopia
}

\author{
Korji Dembi*, Amare Girma, Kebede Basha \\ Oromia Agricultural Research Institute (IQQO), Bore Agricultural Research Center, P.O.BOX 21, Bore, Ethiopia.
}

How to cite this paper: Korji Dembi, Amare Girma, Kebede Basha. (2021) Pre-Extension Demonstration of Improved Maize Technology at Midland Districts of Guji Zone, Southern Oromia, Ethiopia. International Journal of the Science of Food and Agriculture, 5(1), 108-114. DOI: $10.26855 /$ ijfsa.2021.03.015

Received: January 25, 2021

Accepted: February 23, 2021

Published: March 4, 2021

"Corresponding author: Korji Dembi, Oromia Agricultural Research Institute (IQQO), Bore Agricultural Research Center, P.O.BOX 21, Bore, Ethiopia.

Email: korjidembi@gmail.com

\begin{abstract}
Participatory demonstration of improved maize technologies was conducted in two potential midland districts of Guji Zone in 2019. The main objective of the study was to popularize improved maize variety at midlands of Guji Zone. Two districts were selected based on their potential to grow maize and two peasant associations from each district were selected based on their accessibility. Fifteen farmers of gender inclusive were established as Farmers Research Group (FRG) at each peasant association. Three hosting farmers were nominated based on their consent to provide sufficient and suitable land for experiment. Trainings were given for farmers, development agents and subject matter specialists. An improved maize variety (BH-546) with one commercial variety was planted on selected farmers' land with a plot size of $10 \mathrm{~m} \times 10 \mathrm{~m}$. Recommended seed rate of $25 \mathrm{~kg} \mathrm{ha}^{-1}$ with a spacing of $75 \mathrm{~cm}$ and $25 \mathrm{~cm}$ between rows and plants was used respectively. An inorganic fertilizer rate of $100 \mathrm{~kg} \mathrm{ha}^{-1} \mathrm{NPS}$ at planting time and $100 \mathrm{~kg} \mathrm{ha}^{-1} \mathrm{~N}$ with split application $(50 \mathrm{~kg}$ at planting time while $50 \mathrm{~kg}$ at knee height stage). Development agents, subject matter specialists and different stakeholders were participated on organized field visit \& joint monitoring and evaluation. Field day was organized on which different stakeholders participated and experience was shared. Quantitative data such as yield was collected and analyzed using independent $t$ test whereas farmers' feedbacks were analyzed qualitatively. Knowledge change of the farmers was analyzed using dependent $t$ test. Despite the shortage of rain fall, 3.023 tons ha- ${ }^{-1}$ and 2.662 tons ha ${ }^{-1}$ for improved BH-546 and commercial maize variety respectively. Therefore, recommended for pre scaling up.
\end{abstract}

\section{Keywords}

Demonstration, FRG, BH-546

\section{Introduction}

Maize (Zea mays L.) is one of the most important food crops grown world-wide. Among cereal crops, maize has the highest average yield per hectare and remains third after wheat and rice in total area and production in the world [1]. It is grown in most parts of the world over a wide range of environmental conditions [2]. It is one of the most essential cereal crops used in the human diet in most parts of the world and it is an imperative feed constituent for domestic animals. Maize widely cultivated and one of the most important staple food crops and a target of most food security programs in Ethiopia [3]. Maize is one of the most important cereal crops cultivated in Ethiopia ranking second after teff in area coverage and first in total production. The post-harvest crop production survey [3] indicated that out of the total land areas covered by grain crops, $80.71 \%$ is under cereals of which $16.79 \%$ covered by maize and about 8.396 
million tons of grain yields. Maize is grown over a large area in many parts of the country, particularly in southern and southwestern Ethiopia [4]. Despite the large area under maize, the national average yield of maize is about 3.944 tons $\mathrm{ha}^{-1}$ while that of the study areas is about 2.655 tons ha- ${ }^{-1}$ [3]. This is by far below the world's average yield, which is about 5.21 tons $^{-1} \mathrm{a}^{-1}$ [5]. The low productivity of maize is attributed among other, to frequent occurrence of drought, declining of soil fertility, poor agronomic practice, limited use of input, and lack of credit facilities, poor seed quality, diseases, insect pests and weed [6-9].

Midland districts of Guji Zone are potential for maize production. Maize is the main crop used for both household consumption and cash crop. It is an interesting crop in the study areas because the land used for maize is reused for other crop (like teff, haricot bean, chickpea and the like) production helping famers double cropping that enhances their food security and maintains their livelihood. Despite maize is used for human consumption and cash crop in Guji Zone, there is lack of farmers' knowledge on packages of maize and lack of improved, early mature and disease tolerant varieties. But in 2017 production season, different improved varieties were adapted and evaluated both at on farm and on station of Adola Rede sub site, midland of Guji Zone. The result of adaptation study, unpublished data of cereal team of Bore agricultural research center, revealed that BH-546 variety was promising and recommended for demonstration based on high yield ha-1 (BH-546 gave 46.67 quintals ha ${ }^{-1}$ ). Thus, it was depending on that recommendation that the demonstration of improved maize variety, BH-546 was initiated at midland districts of Guji Zone for further awareness creation, promotion of maize and reach more farmers with the main objective to popularize improved maize variety at midlands of Guji Zone.

\subsection{Specific Objectives:}

The specific objectives of the study were to:

(1) Evaluate yield performance of improved maize technologies under farmers' condition;

(2) Create awareness on maize technologies in midland areas;

(3) Improve knowledge and skills of farmers on maize production and management;

(4) Assess farmers' feedbacks for further development of maize;

(5) Evaluate cost-benefit ratio (income of farmers).

\section{Materials and Methods}

\subsection{Description of the Study Areas}

\subsubsection{Adola Rede District}

The district is located in Southern part of Oromia, Ethiopia, at a distance of $468 \mathrm{~km}$ from Finfinne, the capital of Ethiopia. Astronomically the district is located between $5^{\circ} 44^{\prime} 10^{\prime \prime}-6^{\circ} 12^{\prime} 38^{\prime \prime}$ latitudes and $38^{\circ} 45^{\prime} 10^{\prime \prime}-39^{\circ} 12^{\prime} 37^{\prime \prime}$ longitudes. The district is characterized by three agro-climatic zones, namely humid, sub humid and dry arid zones. In terms of the agricultural calendar, the rain fall pattern of the district is bimodal for lowlands and midland areas and mono-modal for highland parts. The dry arid agro-climatic zones attributed to little rainfall while the humid agro-climatic zones receive extremely high rainfall. Rain-fed agriculture is a common practice for many farm households in this district. However, a semi- nomadic economic activity is also practiced as a means of livelihood by some of its dwellers. This district has 29 peasant associations and two urban centers. The farmers of this district produce both in autumn and spring seasons. They produce cereals such as teff, wheat, barley and maize, pulses such as haricot bean, and others such as fruits and vegetables. Overall, wheat, maize and teff are the major crops cultivated by the farmers in these study areas. They also engaged in the production of coffee as means of livelihood.

\subsubsection{Odo Shakiso District}

Odo-Shakiso district is situated at a distance of $490 \mathrm{~km}$ south east from Finfinne and $139 \mathrm{~km}$ from the zone capital town, Negele. The district is classified in to 20 peasant associations. Astronomically, the district is located between $5^{\circ} 2^{\prime} 29^{\prime \prime}-5^{\circ} 58^{\prime} 24^{\prime \prime}$ northing latitudes and 38 $35^{\prime} 0^{\prime \prime}-39^{\circ} 13^{\prime} 38^{\prime \prime}$ easting longitudes. It is boarded by Saba Boru in South and South West, Kercha in West, Adola Rede in the East and Uraga district in the North. The total area of the district is 133,677 ha or $1336.770 \mathrm{~km}^{2}$. The district is characterized by three agro- climatic zones, namely Dega (20\%), weina dega (65) and Kola (15) which starts in early November up to December, late June up to reaches beginning of November and March up to May respectively. The mean annual rain fall is about $900 \mathrm{~mm}$ and the annual temperature of the district is $22.5 \mathrm{c}^{0}$. Most of the earth surface of the district has an undulating land surface with an elevation ranging from 1,500-2,000 meters.

The major soils of the district are chromic eufric and calcic combisal with high spatial coverage of $70 \%$. Camisole found mostly on slopes. Therefore, it has little agricultural potential other mostly developed on gentle slopes, Very good base saturation and fertility are the major important for agricultural production. The remaining portion 30\% mostly covered by orthic acrisols, this soil is fertile and the relative humidity is also quiet suitable for the farm. The farmers of 
this district produce both in autumn and spring seasons. They produce cereals such as teff, wheat, barley and maize, pulses such as haricot bean, and others such as fruits and vegetables. Overall, wheat, maize and teff are the major crops cultivated by the farmers in this study area. They also engaged in the production of coffee as means of livelihood.

\subsection{Sites and Farmers Selection}

Participatory demonstration of improved maize technologies was conducted in two potential midland districts of Guji Zone, Adola Rede and Odo Shakiso. Purposive sampling methods were employed to select two representative districts and two peasant associations from each district based on their potential for maize production and their accessibility.

Participatory approach using Farmers Research Group (FRGs) were the main strategy used during demonstration of the technology. Selection of FRGs member farmers was based on farmers' consent to be held as member, accessibility for supervision of activities, good history of harmony with groups and genuineness and transparency to share innovations to other farmers. To this end, one FRG having 15 members with the arrangement of resource rich, medium and poor class of farmers including gender with proportion of $70 \%$ to $30 \%$ men and women respectively was established at each peasant associations. Three hosting farmers were nominated among FRGs member farmers based on their interest to provide sufficient and suitable land for experiment, vicinity to roads for the chance of being visited by many farmers, initiatives to implement the activity in high-quality, good in field management and willingness to explain the technology to other farmers and share knowledge, skill and experience for further promotion mechanism. Accordingly, three representative trial farmers were selected at each peasant association from each FRG while the rest FRG member regrouped by their village cluster proportionally. One FTC at Odo Shakiso also selected.

Table I. Number of FRG members established in each demonstration site

\begin{tabular}{ccccc}
\hline & & & \multicolumn{2}{c}{ FRG member by gender } \\
\cline { 3 - 5 } Districts (Peasant associations) & No of FRG & Male & Female & Total \\
\hline Adola Rede (Kiltu Sorsa and Gobicha) & 2 & 20 & 10 & 30 \\
Odo Shakiso (Diba Bate and Korba) & 2 & 20 & 10 & 30 \\
Total & 4 & 40 & 20 & 60 \\
\hline
\end{tabular}

\subsection{Materials Used and Field Design}

An improved maize variety (BH-546) with one commercial variety was planted on selected farmers' land with plot of $10 \mathrm{~m} \times 10 \mathrm{~m}$ in the main cropping season. The varieties were treated with full recommended maize production and management packages. The recommended seed rate of $25 \mathrm{~kg} \mathrm{ha}^{-1}$ with a spacing of $75 \mathrm{~cm}$ and $25 \mathrm{~cm}$ between rows and plants respectively was used. The recommended inorganic fertilizer rate of $100 \mathrm{~kg} \mathrm{ha}^{-1}$ NPS at planting time and $100 \mathrm{~kg}$ $\mathrm{ha}^{-1}$ UREA with split application (50 kg at planting time while $50 \mathrm{~kg}$ at knee height stage). All agronomic practices like land preparation-ploughing three to four times using oxen plough, planting, weeding, leveling, harvesting, threshing) were carried out by FRGs member farmers.

\subsection{Technology Demonstration and Evaluation Methods}

For the sake of enhancing efficiency and effectiveness, participatory approach was followed. To this end, FRG members and other follower farmers were encouraged to participate on different extension events organized at each trial site. These were mechanisms used to enhance farmer-to-farmer learning and information exchange such as trainings, field day, joint monitoring and evaluation like regular field visit by extension agents and extension counterparts, at different crop stages etc.

\subsection{Training of Farmers and Development Agents}

The effectiveness of the work is measured in terms of the changes brought about in the knowledge, skill and attitude, and adoption behavior of the people but not merely in terms of achievements of physical targets. Hence, training is very important to bring improvement on the maize production activities to fill the gap on knowledge, skill and attitude (KSA).

Training was given to farmers, Development Agents (DAs), and agricultural experts on maize production methods and management packages. Stakeholders such as district agriculture and natural resource office, cooperative experts were invited and participated during consultation meeting and training. 


\subsection{Field Day}

Field day was arranged to create awareness and farmers shared experience and knowledge. Regular joint monitoring and evaluation (follow up actions) and provision of technical advice were undertaken at different crop stages based on necessary emerging knowledge/skill and technical advice needs. Field day is a method of motivating people to adopt new practices by showing what has already achieved under field conditions. In other words, it is to show the performance and profitability of new practices/technologies/innovations and to convince about the applicability. Besides, it is a way of facilitating people to visit new innovation for the purpose of bringing mass mobilization. Thus, mini field day was organized in order to involve key stakeholders and enhance better linkage among relevant actors. Discussion session and result communication forum were also organized.

\subsection{Data Collection and Analysis Method}

Both qualitative and quantitative data were collected. Grain yield, costs and income gained were collected using data collection sheets. Total number of farmers participated on training, field visits and mini field day were recorded by gender composition. Farmers' feedbacks were collected using checklist by conducting group discussions and key informant interviews.

\subsection{Yield Advantage}

The yield advantage of improved maize technology over commercial is calculated in the following formula.

Yield advantage $\%$ of HB-546 $=$ Yield of new variety - commercial X 100

\section{Commercial}

\subsection{Variety preference ranking}

The variety preference ranking was conducted using group discussions. The farmers were let to observe and set selection criteria at the maturity stage of the crop. The selected criteria were then used to select the preferred variety.

\subsection{Data Analysis}

The collected agronomic data was organized, summarized and analyzed by statistical tools (T test) using Statistical Package for Social Science (SPSS) Version 20. Independent T test was used to compare the mean yield of two independent varieties whereas knowledge level of the farmers about improved production practices of maize before and after the experiment was measured and compared by applying dependent $t$ test. Two samples are said to be dependent on each other when the elements of one are related to those of the other in any significant or meaningful manner. In fact, the two samples consist of observations made of the same objects, individuals or more generally, on the same selected population elements. It helps determine whether the mean difference between paired observations is significant. The dependent $t$ test is often used to compare "before" and "after" scores in experiments for the determination of the significant change that has occurred. The financial data was employed to analysis the costs incurred and the net benefit gained from the production of each variety and location used for the demonstration using excel and presented by table. The calculations were done by converting the parameters per hectare. The final selling price used was the farm gate selling price. Farmers' variety preference was also analyzed qualitatively.

\section{Results and Discussion}

\subsection{Yield Performance of Demonstrated Varieties}

Table 2 below shows the result of yield performance of the varieties demonstrated. According to the results, a mean grain yield of 30.23 and 26.62 quintals ha ${ }^{-1}$ was obtained from BH-546 and commercial varieties, respectively.

Table 2. Comparison of mean yield of maize varieties demonstrated

\begin{tabular}{|c|c|c|c|c|c|c|c|c|}
\hline \multicolumn{9}{|c|}{ Mean yield of maize variety demonstrated (quintals ha-1) } \\
\hline \multirow{2}{*}{ Varieties } & \multirow{2}{*}{$\mathrm{N}$} & \multirow{2}{*}{$\begin{array}{l}\text { Mean[Std. } \\
\text { Deviation] }\end{array}$} & \multirow{2}{*}{$\begin{array}{l}\text { Std. Error } \\
\text { difference }\end{array}$} & \multirow{2}{*}{$\begin{array}{l}\text { Calculated t } \\
\text { value }\end{array}$} & \multirow{2}{*}{$\begin{array}{c}\text { Tabulated t value } \\
\text { at } v=24\end{array}$} & \multirow{2}{*}{ P- Value } & \multicolumn{2}{|c|}{$95 \%$ confidence interval } \\
\hline & & & & & & & Lower & Upper \\
\hline BH-546 & 13 & $30.23[0.83]$ & 0.96 & $3.68 *$ & 1.711 & $0.0436^{*}$ & 1.96 & 5.26 \\
\hline Commercial & 13 & $26.62[0.66]$ & & & & & & \\
\hline
\end{tabular}

*Significant at $5 \%$ probability level, $\mathrm{v}$ is degree of freedom and std. deviation in parenthesis. 
As clearly shown in Table 2 above, information like the calculated t value (3.68) is greater than the tabulated $t$ value (1.711), p-value (0.0436) less than alpha value (0.05) and the confidence interval does not contain zero which indicates that the mean difference in yield between the two varieties were significantly higher. However, the mean yield of pre-extension demonstration of improved maize variety (BH-546) were found to be less than the national average yield of maize, 39.92 quintals ha-1 [3]. This yield difference could be associated with rainfall shortage occurred at the critical stage of the crop during production year, disparities in management practices and the fertility status of the soil. Yet the improved variety (BH- 546) still had an extra $13.56 \%$ yield advantage than the commercial check as indicated in Table 3 .

Table 3. Yield advantage of improved maize variety over the check

\begin{tabular}{ccc}
\hline Varieties & Yield & Yield advantage of improved BH- 546 over the check (\%) \\
\hline BH-546 & 30.23 & 13.56 \\
Commercial & 26.62 & \\
\hline
\end{tabular}

\subsection{Feedbacks and Farmers Preference}

Farmers' preferences toward the demonstrated varieties were assessed by enhancing them to reflect their preference to varietal attributes by setting their own varietal selection criteria. During the demonstration of maize, farmers provide constructive feedback for further research on maize production. Accordingly, the participant farmers preferred improved BH- 546 variety as their first choice.

Table. 4. Direct Matrix ranking of the varieties demonstrated based on farmers preferences $(\mathrm{N}=\mathbf{2 0})$.

\begin{tabular}{ccc}
\hline Variety & Rank & Reasons \\
\hline BH 546 & $1^{\text {st }}$ & Very good yield, drought tolerant, disease tolerant, early mature, high weight, marketable \\
Commercial & $2^{\text {nd }}$ & Good yield, white color, marketable, relatively less weight, susceptible to disease \\
\hline
\end{tabular}

\subsection{Capacity Development}

Table 4 shows the number of farmers, development agents, district office of agriculture experts and other participants who attended training regarding to maize production and management before starting the activity. A total of 76 participants attended the training.

Table 4. Capacity building methods and participants

\begin{tabular}{|c|c|c|c|c|}
\hline \multirow{2}{*}{ Capacity building methods } & \multirow{2}{*}{ Participants } & \multicolumn{3}{|c|}{ Number of participants } \\
\hline & & Male & Female & Total \\
\hline \multirow{3}{*}{ A. Trainings } & Farmers & 45 & 15 & 60 \\
\hline & DAs & 7 & 1 & 8 \\
\hline & SMSs & 8 & - & 8 \\
\hline \multirow{4}{*}{ B. Exchange Visit } & Farmers & 20 & - & 20 \\
\hline & DAs & 3 & 1 & 4 \\
\hline & SMSs & 3 & 1 & 4 \\
\hline & Others & 4 & 1 & 5 \\
\hline \multirow{4}{*}{ C. Field day } & Farmers & 24 & 6 & 30 \\
\hline & DAs & 2 & - & 2 \\
\hline & SMSs & 2 & - & 2 \\
\hline & Others & 2 & - & 2 \\
\hline
\end{tabular}

\subsection{Monitoring and Evaluation}

The activity was monitored majorly by researchers and agriculture and natural resource office of the districts which they represented by the DAs in the kebele administration. The development agents (DAs) see and monitor the activity day to day since they are near to the farmers' jurisdiction and also give technical assistant to the farmers. Joint exchange 
visit, monitoring and evaluation of the activities were conducted among the participating farmers of the districts based on the necessities and requirements. As a result, the group had offered advice based on the practical problem observed on the trial sites.

\subsection{Mini Field Day}

To show the performance of demonstrated varieties, mini field day was organized on which about 36 participants were participated on the event including FRG members to evaluate variety performance.

\subsection{Economic Analysis of Maize Variety Demonstrated}

Production costs and returns of demonstration of maize variety were collected from experimental farmers. Production costs included were variable and fixed costs. Variables costs include cost of land preparation, cost of seeds, cost of fertilizers, planting, weeding, harvesting and transaction cost. Fixed cost referred here was cost of land. This cost was included in this experiment as all the farmers could not owned enough farm land and contract some from their fellow farmers. So, this fixed cost parameter helps us to have insight about the profitability of this crop enterprise for rented farm land as well. During the production season, the average fixed cost of the land for one season was 2,500 ETB ha ${ }^{-1}$ at the study area. Average farm gate price of both maize variety at market during 2019 production season was $7 \mathrm{ETB}^{-1}$. Pre-extension demonstration of maize was profitable with net return of 13,325.61 ETB ha ${ }^{-1}$ and 11,518.61 ETB hafrom BH-546 variety and commercial respectively.

Table 5. Financial analysis

\begin{tabular}{ccccc}
\hline Variable & Cost of cultivation & Growth return & Net return & Benefit cost ratio \\
\hline BH-546 & $7,835.39$ & 21,161 & $13,325.61$ & 1.70 \\
Commercial & $7,115.39$ & 18,634 & $11,518.61$ & 1.62 \\
Additional in demonstration & 720 & 2,527 & 1,807 & $2.51^{*}$ \\
\hline
\end{tabular}

*Incremental benefit cost ratio.

\subsection{Knowledge Level Before and After the Trial Period}

Knowledge level of respondent farmers on various aspects of improved maize production technologies before conducting the demonstration and after implementation was measured and compared by applying dependent $\mathrm{t}$ test. A list of simple yes or no and open ended questions were designed and administered to a total of 12 trial farmers to rate their knowledge level at both pre and post-trial period. The questions were asked during training period before starting the trial and during meeting conducted after the trial to assess farmers' feedback about varieties preference. It could be seen from Table 6 that farmers' mean difference in knowledge score after implementation of demonstration was 14.25. The mean difference in knowledge score of farmers was observed significantly higher. As the computed value of $t$ (33.405) was statistically significant at 5\% probability level. It means there was significant increase in knowledge level of the farmers due to demonstration. This shows positive impact of demonstration on knowledge of the farmers that have resulted in higher adoption of improved farm practices. The results so arrived might be due to the concentrated educational efforts made by the researchers.

Table 6. Comparison between knowledge levels of the respondent farmers about improved farming practices of maize ( $\mathrm{n}=12$ )

\begin{tabular}{cccc}
\hline $\begin{array}{c}\text { Mean of the difference in knowledge } \\
\text { scores }\end{array}$ & $\begin{array}{c}\text { Standard deviation of the difference in } \\
\text { knowledge scores }\end{array}$ & $\begin{array}{c}\text { Calculated } \mathrm{t} \\
\text { value }\end{array}$ & $\begin{array}{c}\text { Tabulated t value at } \\
\mathrm{v}=11\end{array}$ \\
\hline 14.25 & 1.349 & $33.405^{*}$ & 1.796 \\
\hline
\end{tabular}

* Significant at $5 \%$ probability level and $\mathrm{v}$ is degree of freedom.

\section{Conclusions and Recommendations}

The results indicated that the improved variety gave promising yield having a yield advantage of $13.56 \%$ over farmers' (commercial) variety. Furthermore, the improved variety is profitable with incremental benefit cost ratio of 2.5. In terms of farmers' preference, $\mathrm{BH}-546$ variety was selected as first choice by the participating farmers. Therefore, this variety is recommended for up scaling especially at the drought prone areas of the study zone, Guji.

\section{Acknowledgement}

The authors would like to gratitude Oromia Agricultural Research Institute (IQQO) for financially supporting this research work. The staff of Bureau of Agriculture and Natural Resource of Adola Rede and Odo Shakiso districts, 
where the study conducted and FRG household farmers for hosting and implementing the research activities to come up with the intended objectives.

\section{References}

[1] FAOSTAT. (2012). Statistical Database of the Food and Agriculture of the United Nations.

[2] Nigussie, M., Tanner, D., Twumasi, A. S. (2002). Enhancing the Contribution of Maize to Food Security in Ethiopia. Proceedings of the Second National Maize Workshop of Ethiopia, Addis Ababa, Ethiopia.

[3] CSA (Central Statistical Agency). (2018/19). Agricultural Sample survey: report on area and production of major crops (private peasant holdings, Meher season). Statistical Bulletin, Addis Abeba, Ethiopia.

[4] Nega, A., Lemessa, F., Berecha, G. (2016). Distribution and Importance of Maize Grey Leaf Spot Cercospora zeae-maydis (Tehon and Daniels) in South and Southwest Ethiopia. J Plant Pathol Microbial, 7: 362. doi: 10.4172/2157-7471.1000362.

[5] FAO (Food and Agriculture organization of the United Nations). (2011). FAOSTAT online database.

[6] Gezahegn, B., Dagne, W., Lealem, T., Deseta, G. (2012). Maize improvement for low moisture stress areas of Ethiopia: Achievements and Progress in the last decade. In: Worku, M., Twumasi-Afriyie, S., Wolde, L., Tadesse, B., Demisie, G., Bogale, G., Wegary, D. and Matsuoka, Y., Vigorous, Y., Goodman, M.M., Sonchez G., J, Buckler, E., Doebley, J. (2002). A single domestication for maize shown by multilocus microsatellite genotyping. Proceedings of the National Academy of Sciences, 99, 6080-6084.

[7] CIMMYT (International Maize and Wheat Improvement Center). (2004). Second Semi-Annual Progress Report for the Quality Protein Maize Development Project for the Horn and East Africa (XP 31519). July 1-December 31, 2003.

[8] Temesgen, D., Wondimu, F., Kasahun, Z., Wogayehu, W., Takele, N., et al. (2012). Weed management research on maize in Ethiopia. In: Worku, M., Twumasi- Afriyie, S., Wolde, L., Tadesse, B., Demisie, G., Bogale, G., Wegary, D. and Prasanna, B. M. (Eds.). Meeting the Challenges of Global Climate Change and Food Security through Innovative Maize Research. Proceedings of the $3^{\text {rd }}$ National Maize Workshop of Ethiopia. 18-20 April 2011, Addis Ababa, Ethiopia, pp. 128-133.

[9] Tewabech, T., Dagne, W., Girma, D., Meseret, N., Solomon, A., et al. (2012). Maize pathology research in Ethiopia in the 2000s: A review. In: Worku, M., Twumasi-Afriyie, S., Wolde, L., Tadesse, B., Demisie, G., Bogale, G., Wegary, D. and Prasanna, B. M. (Eds.). Meeting the Challenges of Global Climate Change and Food Security through Innovative Maize 23. Research. Proceedings of the $3^{\text {rd }}$ National Maize Workshop of Ethiopia.18-20 April 2011, Addis Ababa, Ethiopia, pp. $193-202$. 